\title{
Socio-Economic Status and Satisfaction with Service Delivery among Students in Federal Universities in South-South Nigeria
}

\author{
Dr. James E. Okon \\ Dept. of Educational Administration and Planning \\ University of Calabar, Calabar, Nigeria. \\ Dr. Roseline M. Akpoiroro \\ Dept. of Educational Administration and Planning \\ University of Calabar, Calabar, Nigeria.
}

\begin{abstract}
The study was designed to investigate the level of students' satisfaction with service delivery in federal Universities in South-South geopolitical zone of Nigeria on the basis of their socio-economic status. To carry out the study, the hypotheses was formulated and literature reviewed. Using the stratified random sampling technique 1,700 students out of a population of 70,808 formed the study's sample. They were Years One, Two, Three, and Four regular undergraduate students of the $2008 / 2009$ to $2011 / 2012$ academic years in federal universities in south-south Nigeria. Data collected for this study was obtained through a face-validated Students' Satisfaction with Service Delivery Questionnaire (SSSDQ) with a test-retest reliability estimate of 71 to 83 . The instrument was administered to the 1,700 respondents, but only 1,450 copies were properly filled and used to assess the students' satisfaction with service delivery in their universities based on their socio-economic status. Data collected was analyzed using descriptive statistics and a one-way analysis of variance (ANOVA). The major findings was that student's socio-economic status significantly influenced their satisfaction with educational, library, medical, security, transport, hotel, and ICT services. Based on the findings, it was recommended that the quality of services rendered to students should constantly be monitored and upgraded to meet up with their satisfaction across socio-economic statuses.
\end{abstract}

Key words: Socio-economic status, services, students' satisfaction

\section{INTRODUCTION}

No matter the socio-economic status of students who populate a given university, they have been categorized as the primary beneficiaries of university-mediated service delivery and so should be treated as customers. Within the higher education sector, university students' satisfaction is an important component of attracting and retaining high achievers who in turn increase the reputation and standing of the university.

Universities in Nigeria are expected to maintain "...high standards in the quality of facilities, services and resources..." (Federal Republic of Nigeria, 2013:27). The implication of this is that universities that intend to produce competent students who would be able to do the jobs diligently upon graduation, must deliver quality services without much ado about the students' socio-economic status. When quality services are delivered, it would lead to satisfaction among students. 
There are several services which federal universities, such as those in south-south Nigeria, could render to their students. These could be educational, library, medical security, transport, hostel and information and communication technology (ICT) services. In this study, the researchers were out to investigate whether or not students' satisfaction with university service delivery was dependent on students' high, average or low socio-economic status.

The socio-economic status of a learner is most commonly determined by combining parents' educational level, occupational status, and income level (Jeynes, 2002). The level of satisfaction for every student is very subjective due to their culture, background and status. Some students might be satisfied after using the facilities provided by the university because of their family background/socio-economic status. Students from the low and middle classes might be satisfied with the basic facilities provided by the universities while a student from the high class or a rich family might have higher expectations on facilities provided (Alshurideh, 2012).

Socio-economic status is also important in determining students' residential satisfaction. As stated by Parkers, Kearns and Atkinson (2002); Frank, and Enkawa (2009), individuals with higher income can afford to live in the affluent residential areas. For students, socio-economic status can be judged through their family backgrounds or other financial supports such as scholarship, study loan or part-time work. Amole (2007), and Thomsen and Eikemo (2010) posited that students with higher socio-economic status could afford to rent rooms with better qualities provided in the students housing as they desire. According to Curtis and Klapper (2005), students who come from wealthy families usually chose to stay in rented houses or flats rather than in the university's student housing. This scenario shows that students with high socio-economic status are not usually satisfied with university hostels. Connor, Pearson, Pollard, Tyers and Willison (2001) in their study on making choice of university, found that students' from higher socio-economic groups with greater levels of family income were generally more satisfied with their choice of institution.

\section{THE PROBLEM}

Behind some troubles, riots and violent eruptions in the academic environment, students' dissatisfaction with service delivery reflective of their socio-economic status may be responsible. The fact that students of federal universities in the south-south geopolitical zone of Nigeria actually rioted against service delivery in 2011, 2012 and 2013 portrays the fact of their discontent with university-provided services. Cases in point were the riot in the University of Calabar in 2011 against increased school charges, the disruption of academic activities in the University of Port Harcourt in 2012 against insecurity in the university environment, and the unruly behavior recorded by students of the University of Uyo in 2013 against hiked and inappropriate inter-campus transport arrangement for them. In all three cases, the universities closed for weeks if only to avert more disaster. The students who rioted cut across all socio-economic backgrounds. This had undesirable consequences for the universities in question.

Poor service delivery to students has been observed to beset the academic atmosphere of federal, public universities in Nigeria over time such as those mentioned above. Educational, library, medical, security, transport, hostel, and ICT services to students, whether concentrated in the universities or outsourced, have been hardly satisfying to them. The dimension of students' socio-economic status and their satisfaction with service delivery has been noted in literature and from the researchers' personal experience and thought to be a potential problem if not addressed. The problem therefore seems to be located around the question, "Are students' satisfaction with universities service delivery contingent upon their socio-economic status?" 


\section{Research Question}

How does students' socio-economic status influence their satisfaction with the delivery of different services?

\section{Hypothesis}

Ho: Students' satisfaction with the delivery of educational services, library services, medical services, transport services, security services, hostel services, and ICT services does not significantly depend on their socio-economic status (high, average, low).

\section{METHODOLOGY}

The Ex-post facto design was used for the study. The population of the study consisted originally of 70,808 regular undergraduate students in 238 departments in 46 faculties in the $2008 / 2009$ to $2011 / 2012$ academic years in the six federal universities in the south-south geopolitical zone of Nigeria. But this was further limited to 12 faculties in the Universities of Calabar, Port Harcourt, and Uyo after using the random sampling technique. The sample of the study was 1,700 students. Owing to attrition, 1,450 questionnaire copies were returned filled. A four-point likert-type scale (questionnaire) was used for data collection for the study. It was known as Students Satisfaction with Service Delivery Questionnaire (SSSDQ). It had Parts 1 and 2. While Part 1 concentrated on respondents' demographics which took care of the independent variables and its sub- variables. Part 2 elicited responses on the dependent variables. The positively-worded items were scored on a scale of Strongly Agree $=20$ points; Agree $=15$ points; Disagree $=10$ points; Strongly Disagree $=5$ points. This was reversed for negatively-worded items. The 35 -item instrument was face-validated by two experts in Measurement and Evaluation in the University of Calabar.

The reliability of the instrument was ascertained through the conduct of a trial test on 50 students sampled from the University of Calabar. The 50 students were from a faculty exempted from the main study. The instrument was administered twice to this sample at two weeks interval. Data from the responses were obtained and used in preparing an item-person matrix with which test-retest reliability estimate was done. Test-retest reliability estimates ranging from .71 to .83 were obtained for the subsets of the questionnaire.

\section{Research Question}

\section{RESULTS}

How does students' socio-economic status influence their satisfaction with the delivery of different services?

The analysis of the research question is captured in Table1.

Table 1: Summary of descriptive statistics showing the delivery of student- related services in the study $(n=1450)$

\begin{tabular}{llccc}
\hline $\mathbf{S} / \mathbf{N}$ & Variables & $\mathbf{N}$ & $\mathbf{X}$ & SD \\
\hline 1 & Educational services & 1450 & 12.84 & 2.72 \\
2 & Library services & 1450 & 11.83 & 2.38 \\
3 & Medical services & 1450 & 12.05 & 2.75 \\
4 & Transport services & 1450 & 12.46 & 2.54
\end{tabular}


$5 \quad$ Security services

$6 \quad$ Hostel services

$7 \quad$ ICT services
1450

1450

1450
11.77

12.94

12.87
2.92

2.58

2.75

Source: Statistical package for social sciences

The descriptive statistics were used as a basis for computing the one-way analysis of variance (ANOVA) of the influence of students' socio-economic status on their satisfaction with service delivery.

\section{Hypothesis}

Ho: Students' satisfaction with the delivery of educational services, library services, medical services, transport services, security services, hostel services, and ICT services does not significantly depend on their socio-economic status (high, average, low).

The independent variable in this hypothesis is students' socio-economic status classified into three (High, Average, and Low) while the dependent variable is students' satisfaction with service delivery classified into seven services. A One-way analysis of Variance (ANOVA) statistical test was employed in testing the hypothesis. Results of the analysis were presented in Tables 2, 3 and 4.

Table 2: Descriptive statistics for the influence of students' socio-economic status on their satisfaction with service delivery

\begin{tabular}{|c|c|c|c|c|c|}
\hline $\mathbf{S} / \mathbf{N}$ & Variables & Socio-economic status & $\mathbf{N}$ & $\overline{\bar{X}}$ & SD \\
\hline 1 & Educational services & $\begin{array}{c}\text { High } \\
\text { Average } \\
\text { Low } \\
\text { Total }\end{array}$ & $\begin{array}{c}309 \\
940 \\
201 \\
1450\end{array}$ & $\begin{array}{l}12.94 \\
12.89 \\
12.49 \\
12.84\end{array}$ & $\begin{array}{l}3.27 \\
2.61 \\
2.21 \\
2.27\end{array}$ \\
\hline 2 & Library services & $\begin{array}{c}\text { High } \\
\text { Average } \\
\text { Low } \\
\text { Total }\end{array}$ & $\begin{array}{c}309 \\
940 \\
201 \\
1450\end{array}$ & $\begin{array}{l}12.52 \\
11.65 \\
11.58 \\
11.83\end{array}$ & $\begin{array}{l}2.02 \\
2.48 \\
2.19 \\
2.38\end{array}$ \\
\hline 3 & Hostel services & $\begin{array}{l}\text { High } \\
\text { Average } \\
\text { Low } \\
\text { Total }\end{array}$ & $\begin{array}{c}309 \\
940 \\
201 \\
1450\end{array}$ & $\begin{array}{l}11.90 \\
11.87 \\
13.12 \\
12.05\end{array}$ & $\begin{array}{l}3.20 \\
2.58 \\
2.50 \\
2.75\end{array}$ \\
\hline 4 & Transport services & $\begin{array}{c}\text { High } \\
\text { Average } \\
\text { Low } \\
\text { Total }\end{array}$ & $\begin{array}{c}309 \\
940 \\
201 \\
1450\end{array}$ & $\begin{array}{l}12.06 \\
12.67 \\
12.03 \\
12.46\end{array}$ & $\begin{array}{l}1.87 \\
2.66 \\
2.69 \\
2.54\end{array}$ \\
\hline 5 & ICT services & $\begin{array}{c}\text { High } \\
\text { Average } \\
\text { Low } \\
\text { Total }\end{array}$ & $\begin{array}{c}309 \\
940 \\
201 \\
1450\end{array}$ & $\begin{array}{l}12.22 \\
12.27 \\
11.81 \\
11.77\end{array}$ & $\begin{array}{l}2.76 \\
2.86 \\
2.60 \\
2.92\end{array}$ \\
\hline 6 & Security services & $\begin{array}{c}\text { High } \\
\text { Average }\end{array}$ & $\begin{array}{l}309 \\
940\end{array}$ & $\begin{array}{l}13.77 \\
12.64\end{array}$ & $\begin{array}{l}2.10 \\
2.54\end{array}$ \\
\hline
\end{tabular}




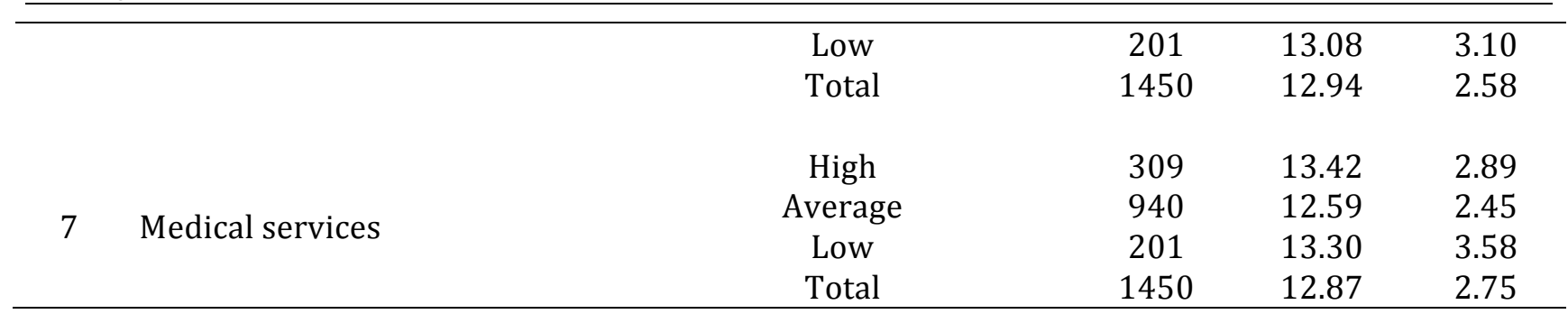

Source: Statistical Package for Social Sciences

Table 3: One-way analysis of variance (ANOVA) of the influence of students' socio-economic status on their satisfaction with service delivery

\begin{tabular}{|c|c|c|c|c|c|c|}
\hline $\mathbf{S} / \mathbf{N}$ & Variables & $\begin{array}{l}\text { Source of } \\
\text { variation }\end{array}$ & SS & Df & $\overline{\mathbf{M S}}$ & $\mathbf{F}$ \\
\hline 1 & $\begin{array}{l}\text { Educational } \\
\text { services }\end{array}$ & $\begin{array}{c}\text { Between } \\
\text { Within } \\
\text { Total }\end{array}$ & $\begin{array}{c}28.981 \\
10664.536 \\
10693.517\end{array}$ & $\begin{array}{c}2 \\
1447 \\
1449\end{array}$ & $\begin{array}{c}14.491 \\
7.370\end{array}$ & 1.966 \\
\hline 2 & Library services & $\begin{array}{c}\text { Between } \\
\text { Within } \\
\text { Total }\end{array}$ & $\begin{array}{c}187.909 \\
7998.988 \\
8186.897\end{array}$ & $\begin{array}{c}2 \\
1447 \\
1449\end{array}$ & $\begin{array}{c}93.954 \\
5.528\end{array}$ & $16.996^{*}$ \\
\hline 3 & Hostel services & $\begin{array}{c}\text { Between } \\
\text { Within } \\
\text { Total }\end{array}$ & $\begin{array}{c}270.402 \\
10656.219 \\
10926.621\end{array}$ & $\begin{array}{c}2 \\
1447 \\
1449\end{array}$ & $\begin{array}{c}135.201 \\
7.364\end{array}$ & $18.395^{*}$ \\
\hline 4 & Transport services & $\begin{array}{c}\text { Between } \\
\text { Within } \\
\text { Total }\end{array}$ & $\begin{array}{c}128.673 \\
9190.586 \\
9319.586\end{array}$ & $\begin{array}{c}2 \\
1447 \\
1449\end{array}$ & $\begin{array}{c}64.336 \\
6.352\end{array}$ & $10.129 *$ \\
\hline 5 & ICT services & $\begin{array}{c}\text { Between } \\
\text { Within } \\
\text { Total }\end{array}$ & $\begin{array}{c}978.684 \\
11376.212 \\
12354.897\end{array}$ & $\begin{array}{c}2 \\
1447 \\
1449\end{array}$ & $\begin{array}{c}489.342 \\
7.862\end{array}$ & $62.242^{*}$ \\
\hline 6 & Security services & $\begin{array}{c}\text { Between } \\
\text { Within } \\
\text { Total }\end{array}$ & $\begin{array}{c}299.726 \\
9335.860 \\
9635.586\end{array}$ & $\begin{array}{c}2 \\
1447 \\
1449\end{array}$ & $\begin{array}{c}149.863 \\
6.452\end{array}$ & $23.228^{*}$ \\
\hline 7 & Medical services & $\begin{array}{l}\text { Between } \\
\text { Within } \\
\text { Total }\end{array}$ & $\begin{array}{c}204.391 \\
10780.712 \\
10985.103 \\
\end{array}$ & $\begin{array}{c}2 \\
1447 \\
1449 \\
\end{array}$ & $\begin{array}{c}102.196 \\
7.450\end{array}$ & $13.717^{*}$ \\
\hline
\end{tabular}

*Significant at .05 , critical $\mathrm{F}=3.00$

Source: Statistical Package for social Sciences

Results of analysis in Table 2 meant that it was students from high socio-economic status that were more satisfied with library services $(\mathrm{x}=12.52)$, security services ( $\mathrm{x} 13.77)$, and medical services $(\mathrm{x}=13.42)$ than their counterparts from average and low socio-economic status. This implies that, the higher the socio-economic status of the students the more satisfied they were with library, security and medical services. The results also showed that students from low socio-economic status were more satisfied with hostel services than their counterparts from high and average socio-economic status. This revealed the lower the socio-economic status of students the more satisfied they were with hostel services in their schools. 
Results of analysis in Table 3 show that the calculated F-ratios for the influence of students' socio-economic status on their satisfaction with library (16.996), hostel (18.359), transport (10.129), ICT (62.242), security (23.228), and medical (13.717) services were each greater than the critical F-ratio of 3.00 at .05 level of significance with 2 and 1447 degrees of freedom. This means that students' socio-economic status significantly influenced their satisfaction with the provision of those services enumerated above. Based on these results, the null hypothesis was rejected. The results however showed that there was no significant influence of students' socio-economic status on their satisfaction with educational services (1.966).

Since the results were significant for some of the variables compared with levels of socioeconomic status, a post-hoc comparison among group means was carried out using Fisher's Least Significant Difference (LSD) method to determine the pair-wise group means difference(s) responsible for the influence. Results of the analysis are presented in Table 4.

Table 4: Fisher's LSD of the influence of students' socio-economic status on their satisfaction with service delivery

\begin{tabular}{|c|c|c|c|c|c|}
\hline $\mathbf{S} / \mathbf{N}$ & Variables & Socio-economic status & $\begin{array}{c}\text { High } \\
(\mathrm{n}=309)\end{array}$ & $\begin{array}{l}\text { Average } \\
(\mathrm{n}=940)\end{array}$ & $\begin{array}{c}\text { Low } \\
(n=201)\end{array}$ \\
\hline 1 & Library services & $\begin{array}{c}\text { High } \\
\text { Average } \\
\text { Low }\end{array}$ & $\begin{array}{c}12.52^{\mathrm{a}} \\
5.65^{\mathrm{c}} \\
4.48\end{array}$ & $\begin{array}{c}0.87 \mathrm{~b} \\
11.65 \\
0.38\end{array}$ & $\begin{array}{c}0.94 \\
0.71 \\
11.58\end{array}$ \\
\hline 2 & Hostel services & $\begin{array}{c}\text { High } \\
\text { Average } \\
\text { Low }\end{array}$ & $\begin{array}{l}11.90 \\
2.89^{*} \\
4.96^{*}\end{array}$ & $\begin{array}{c}0.03 \\
11.87 \\
5.93^{*}\end{array}$ & $\begin{array}{c}1.23 \\
1.26 \\
13.12\end{array}$ \\
\hline 3 & Transport services & $\begin{array}{l}\text { High } \\
\text { Average } \\
\text { Low }\end{array}$ & $\begin{array}{c}12.06 \\
3.70^{*} \\
1.54\end{array}$ & $\begin{array}{c}0.61 \\
12.67 \\
3.28^{*}\end{array}$ & $\begin{array}{c}0.35 \\
0.64 \\
12.03\end{array}$ \\
\hline 4 & ICT services & $\begin{array}{c}\text { High } \\
\text { Average } \\
\text { Low }\end{array}$ & $\begin{array}{c}10.22 \\
11.39^{*} \\
6.22^{*}\end{array}$ & $\begin{array}{c}2.05 \\
12.27 \\
2.02\end{array}$ & $\begin{array}{c}1.58 \\
0.46 \\
11.81\end{array}$ \\
\hline 5 & Security services & $\begin{array}{c}\text { High } \\
\text { Average } \\
\text { Low }\end{array}$ & $\begin{array}{l}13.77 \\
6.78^{*} \\
3.00^{*}\end{array}$ & $\begin{array}{c}1.13 \\
12.64 \\
2.23^{*}\end{array}$ & $\begin{array}{c}0.69 \\
0.44 \\
13.08\end{array}$ \\
\hline 6 & Medical services & $\begin{array}{c}\text { High } \\
\text { Average } \\
\text { Low }\end{array}$ & $\begin{array}{l}13.42 \\
6.31^{*} \\
2.79^{*}\end{array}$ & $\begin{array}{c}1.13 \\
12.59 \\
2.07^{*}\end{array}$ & $\begin{array}{c}0.69 \\
0.44 \\
13.30\end{array}$ \\
\hline
\end{tabular}

*Significant at .05

Source: Statistical Package for Social Sciences

a) Group means are along the principal diagonals

b) Differences among group means are above the principal diagonals

c) t-values are below the principal diagonals

Results of analysis in Table 4 show significant pair-wise group differences as follows: library services-High versus Average $(\mathrm{t}=5.65, \mathrm{p}<05)$ and High versus Low $(\mathrm{t}=4.48, \mathrm{P}<.05)$, Hostel services-High versus Low $(\mathrm{t}=2.89, \mathrm{p}<.05)$, and Average versus low $(\mathrm{t}=4.96, \mathrm{p}<.05)$; Transport-High versus Average $(t=3.70, p<.05)$, and Average versus Low $(t=3.28, p<.05)$; ICT 
services - High versus Average $(\mathrm{t}=11.39, \mathrm{p}<.05)$, High versus Low $(\mathrm{t}=6.22, \mathrm{p}<.05)$, and Average versus Low $(t=2.02, p<.05)$; Security services - High versus Average $(t=6.78, p<.05)$, High versus Low $(\mathrm{t}=3.00, \mathrm{p}<.05)$, and Average versus Low $(\mathrm{t}=2.23, \mathrm{p}<.05)$; Medical services High versus Average $(\mathrm{t}=6.31, \mathrm{p}<.05)$ and Average versus Low $(\mathrm{t}=2.79, \mathrm{p}<.05)$.

\section{DISCUSSION}

The results of analyses in this study show that the calculated F-ratios for the influence of students' socio-economic status on their satisfaction with library (16.996), hostel (18.359), transport (10.129), ICT (62.242), security (23.228), and medical (13.717) services were each greater than the critical F-ratio of 3.00 at .05 level of significance and with 2 and 1447 degrees of freedom. This means that students' socio-economic status significantly influenced their satisfaction with the delivery of those services enumerated above. The results however showed that there is no significant influence of students' socioeconomic status on their satisfaction with educational services. Students from high socio-economic status were more satisfied with library, security, and medical services while those from average socio-economic status were more satisfied with transport and ICT services, and those from low socio-economic status were more satisfied with hostel services. These findings agree with the work of Alshurideh (2012) who posited that the level of satisfaction for every student is very subjective due to their socio-economic status. Some students might be satisfied after using the facilities provided by the university because of their socio-economic status. Students from low and average classes tended to be satisfied with basic facilities while students from the high class might have higher expectations of facilities provided. Thomsen and Eikemo (2010) also noted that students with high socio-economic status were not usually satisfied with university hostels, for example.

\section{CONCLUSION}

From the findings of the study, it could be concluded that the socio-economic status of students influenced their satisfaction with university service delivery reflective of their socio-economic bracket. Students from low socio-economic background could be easily satisfied with the services and facilities in federal public universities. But high socio-economic status students may be hard-to-please in terms of service delivery owing to their socio-economic status.

\section{Recommendation}

Based on the conclusion of this study, the recommendation below is made:

1. In order to meet students across socio-economic statuses, the quality of educational, library, medical, transport, security, hostel, and ICT facilities and services should be of standard, be constantly upgraded, and be maintained rigorously by federal university authorities.

\section{References}

Alshurideh, M. (2012).The factors predicting students' satisfaction with universities' health care clinics' services: A case study from the Jordanian Higher Education sector. Research Journal of International Studies, Issue 23, 173188.

Amole, D. (2009), “Residential satisfaction in students' housing”. Journal of Environment Psychology, 29 (1), $76-$ 85.

Connor, H., Pearson, E., Pollard, C. T., \& Willison, R. (2001). Making the right choice: How students choose universities and colleges. Universities UK, London.

Curtis, S. \& Wapper, R. (2005). Financial support systems: the student experience in England and France. International Journal of Social Economics, 32,121-132.

Federal Government of Nigeria (2013). National Policy on Education (6th Edition), Abuja: NERDC press. 
Frank, B. \& Enkawa, T. (2009). Economic drivers of dwelling satisfaction, evidence from Germany. International Journal of Housing markets and Analysis, 2(1), 6-20.

Gronroos, C. (1984). A service quality model and its marking implications. European Journal of Marketing 18(4), 36.

Parkers, A., Kearns, A., \& Atkinson, R. (2002). What makes people dissatisfied with neighborhoods. Urban studies, 39(13), 2413-2438

Thomson, J. \& Eikemo, T.A. (2010). Aspects of students housing satisfaction: A qualitative study. Journal of Housing and the Built Environment, 25(2), 273-293. 